seignorial power, especially the mals usos (bad customs) that tied peasants to the land. Finally, boundary disputes between Aragon and Old Catalonia over New Catalonia led to the erosion of many customary laws that disadvantaged the monarchy. By the book's end, then, Jaume I and his successors, mainly Pere II and Jaume II, have gained direct rule over Lleida and Tortosa, though nobles retained power outside the cities.

Victory's Shadow has much to commend it for an upper-level history course and scholars interested in Catalonian society, lordship, or royal power. Barton does a masterful job interpreting a wide variety of published and unpublished charters, coins, court cases, and law codes from well-known archives, like the Archivo de la Corona de Aragón, as well as less commonly utilized institutions in Lleida and Tortosa. Surprisingly, Barton does not discuss the foundation of those archives, which occurred under Jaume I. Indeed, Robert I. Burns, whose 1985 introductory volume to the Diplomatarium of the Crusader Kingdom of Valencia remains the standard English history of the Crown's archives, claimed, "An array of lawyers and scribes was more vital to [Jaume's] achievement than were the contingents of crossbowmen and knights" (9).

Barton does much to support Burns's assertion, particularly in the twelfth century. Charters of settlement, surveys by Bertran de Castellet and Ponç the Scribe, the Usatges de Barcelona, Liber feudorum maior, and other documents enhanced the count-kings' fiscal efficiency and accountability over their aristocracy and allowed them to maintain their conquests. Yet Barton does not trace how these initial "rudimentary and unsystematic" parchments evolved into one of Europe's best kept archival systems, a key factor in comital-royal authority from the thirteenth century onward (96). In other words, the Crown of Aragon's victory over New Catalonia might have cast an even longer shadow than Barton suggests.

Michael J. Sanders, Fordham University doi: $10.1017 /$ rqx.2020.362

\title{
Life in a Time of Pestilence: The Great Castilian Plague of 1596-1601. Ruth MacKay. \\ Cambridge: Cambridge University Press, 2019. xiv + 276 pp. \$39.99.
}

It is something to be writing this review in March 2020, as COVID-19 spiderwebs its way across the globe. Historians and journalists are dining out on op-eds and book reviews drawing comparisons with social and political responses to the Black Death and later plague cycles. We are enthusiastic about the opportunity to make our work immediately meaningful for the broad public. Hannah Marcus reminds us in the New York Times not to give in to xenophobia and fear mongering (New York Times, 1 March 2020) and Erin Maglaque takes us into the empty streets of Florence in 1630 in the London Review of Books (42.4, 20 February 2020). In these pieces we 
read how past societies turned on themselves and on outsiders, and how human foibles like friendship and the need to feed families frustrated the misguided efforts of city governments to quarantine people against the spreading sickness.

Ruth MacKay's refreshing take on the history of Castile's devastating plague of 1596-1601 offers another way of interpreting human behavior during times of epidemic and fear. The argument of her book, handsomely bound in a contemporary map of plague-stricken Castilian towns, is that while thousands sickened and died as plague moved inland from the coast of the Bay of Biscay, in many ways life continued apace. This is not to say that MacKay argues for a normality of plague experience; rather, she makes the compelling case that the machinery of social, political, and economic life struggled on as best it could, as it had before. By no means did this continuity help prevent the spread of plague. It likely worsened it. But MacKay argues richly, with a deep reading of a wide variety of documents, that rather than focus on the crises and disruption that plague can bring (as I am guilty of in my recent monograph on Italian homicide), historians might find more ordinary and more intriguing histories by looking into the many ways in which life went on despite the rising death toll.

MacKay situates her argument spatially, taking us to the sites of Castilian life in eponymous chapters: "Palace," for a broad view of royal politics and legislation; "Road," for the experiences of travelers, messengers, and merchants; "Wall," where guards were newly empowered to protect gates and citizens sought to evade their attention. In the "Market," city councils attempted to ameliorate an "excruciating need for grain" (119), as marketplaces emptied out and people starved. The "Street" became ghostly as the wealthy and clerical fled cities, as single women and the immigrant poor were expelled, and as street processions were canceled. The "Townhall" continued to adjudicate local conflicts, and municipal decisions shaped local responses to the advent of plague. As pestilence unleashed its fury, medical men and physicians remained with patients in "Sickbed," treating the condition as they could and offering comfort where they could not.

MacKay argues that in all these sites plague was part and parcel of early modern life. Subsequent city chronicles and histories did not dwell on the experience because "there was nothing much to say" (247). Plague happens. It happened in 1596-1601 in Castile, and it happened again in 1647-51, among other times. For these early modern Spaniards, "it was a part of their memory. They knew what to do" (247). One senses that if one is looking for continuity in times of pestilence, one can find it; if one is looking for chaos, one can find that too. MacKay does not dwell, for instance, on the consequences of the expulsion of thousands of starving poor from urban centers into the surrounding countryside. Spending some more time in criminal records might reveal unusual patterns of violence, which may have had long-term consequences for civil society.

But that is only if one seeks chaos: MacKay's beautifully written account of the Castilian pestilence shows us the usual business of plague. Stories of individual lives, 
often cut short, make the plague a very human experience here. MacKay's admirable work in many Spanish archives gives us a thick view of the continuation of life, as the bodies piled up at the turn of the seventeenth century.

Colin Rose, Brock University doi: $10.1017 /$ rqx.2020.363

\section{Exceptional Crime in Early Modern Spain: Taxonomic and Intellectual} Perspectives. Elena del Río Parra, ed.

The Medieval and Early Modern Iberian World 68. Leiden: Brill, 2019. xii + 218 pp. $€ 95$.

Relying primarily on "private correspondence, gazettes, diaries, and chapbooks," with a few references to legal texts (2), Elena del Río Parra's study attempts to illuminate shifts in early modern ideas about classification and representation of extremely violent killings and death. The study is divided into five chapters, covering a wide spectrum of topics-from the singular killing/killer to the serial killer and to suicide-and the study looks into an eclectic mixture of concepts that at times are not easily conceptualized. Nevertheless, in a myriad of points and counterpoints that makes for a methodological labyrinth, one can discern at least two key objectives.

First, the author aims to explore the evolution of categories to explain the strange, the anomalous, the grotesque, the deformed, and the monstrous races, a phenomenon already evident in Pliny the Elder's encyclopedic study of plants and animals, produced nearly two thousand years ago. By the sixteenth century, this phenomenon transitioned to the individualization of the exceptional, which ultimately led to the idea of a subspecies linked to criminality. As the author explains, the rise of the scientific method of the sixteenth and seventeenth centuries fueled debates about human nature and led to an increased readership for catastrophic tales and sensationalist accounts of depraved human activity. In fact, by the seventeenth century, physiognomists had created a criminal archetype, as exemplified by the Spanish Esteban Pujasol, who in 1637 claimed to have found criminal characteristics in a murderer's eyeball.

Río Parra's second objective is to question the conventional divide between high and low literature, the latter commonly viewed as a source of popular stories that relied on meretricious accounts of crime and violence. Perhaps predictably, her findings indicate that both learned and illiterate consumers of horror stories enjoyed anecdotes relating to violence as forms of entertainment (49-50). The thirst for lurid details of abominable events, of all possible imaginable carnage, knew no class boundaries. Furthermore, in her examination of the gap between "historical records and poetic material" (60), the author found that readers did not necessarily care whether stories of heinous crimes were true or false, wanting only to be "amused, entertained and shocked" (111). Indeed, Río 